\title{
Når seponere bisfosfonater?
}

\author{
De seneste årene har man observert sjeldne, men alvorlige bivirkninger under langtidsbehandling \\ med bisfosfonater. I denne artikkelen drøfter vi om og når det er grunnlag for å seponere bisfosfonat.
}

\section{Erik Fink Eriksen}

e.f.eriksen@medisin.uio.no

Endokrinologisk avdeling

Oslo universitetssykehus

og

Spesialistsenteret Pilestredet Park

\section{Johan Halse}

Osteoporoseklinikken

Spesialistsenteret Pilestredet Park

Bisfosfonater har i snart 20 år vært de hyppigst brukte legemidlene til behandling av osteoporose. Via hemming av beinresorpsjonen reduserer de risikoen for frakturer i rygg, hofte og resten av skjelettet (ikkevertebrale frakturer) med hhv. 40-70\%, $40-50 \%$ og $15-25 \%(1-3)$. Medikamentene har vært brukt av millioner av osteoporosepasienter og har en gunstig risikoprofil (1-3). For orale bisfosfonater er de vanligste bivirkningene kvalme og dyspepsi, sjeldnere oesophaguserosjoner og magesår. For intravenøse bisfosfonater er den hyppigste bivirkningen influensaliknende symptomer (postdosesymptomer).
De seneste årene har man imidlertid observert kjevebeinsosteonekrose og atypiske femurfrakturer under langtidsbehandling med bisfosfonater. Varigheten av bisfosfonatbehandling er derfor satt under debatt. Vi har utført et søk i PubMed og valgt referanser til denne artikkelen på bakgrunn av vår erfaring som forskere og klinikere innen osteoporosefeltet.

\section{Hvorfor stoppe bisfosfonatbehandling?}

En hypotetisk bivirkning av langvarig bisfosfonatbehandling er nær stopp i beinremodelleringen (frozen bone). Dette ville medføre at de normale reparasjonsprosessene opphørte og man fikk akkumulasjon av mikrosprekker i beinvevet, som over tid kunne utvikle seg til kliniske brudd. Denne bekymringen økte etter at man publiserte ni tilfeller med disse karakteristikaene etter langvarig alendronatbruk (4). Senere ble det imidlertid publisert en studie av 1000 pasienter behandlet med alendronat med 5-10 års oppfølgingstid, FLEX-studien. Denne studien var en videreføring av de opprinnelige hovedstudiene av alendronats frakturforebyggende effekt og viste at denne bekymringen var uberettiget (5). Hvis akkumulering av mikrosprekker hadde vært en reell bivirkning ved langvarig bisfosfonatbehandling, ville man forvente at pasienter over tid utviklet flere frakturer. Dette var ikke tilfellet. Tvert imot var reduksjonen av frakturer konstant over ti år, og faktisk hadde pasienter som fikk kalsium og vitamin $\mathrm{D}$ alene etter fem års alendronatbehandling signifikant flere brudd i ryggen enn pasienter som fortsatte $i$ ti år med aktiv behandling (5).

For alle bisfosfonater er det beskrevet to meget sjeldne bivirkninger, som begge har vært gjenstand for intens debatt de siste årene, nemlig kjevebeinsosteonekrose og atypiske femurfrakturer. Disse bivirkningene er imidlertid så sjeldne, med risikoestimater på 1/10 000-1/100 000, at de i liten grad påvirker den gunstige risiko-effekt-ratioen for bisfosfonater $(6,7)$. En direkte patogenetisk sammenheng med bisfosfonatbruk mangler, men man har kartlagt en rekke andre risikofaktorer som disponerer for kjevebeinsosteonekrose og atypiske frakturer. Da disse to bivirkningene er assosiert med lengre tids bruk av bisfosfonater (> 5-10 år), har man likevel i økende grad
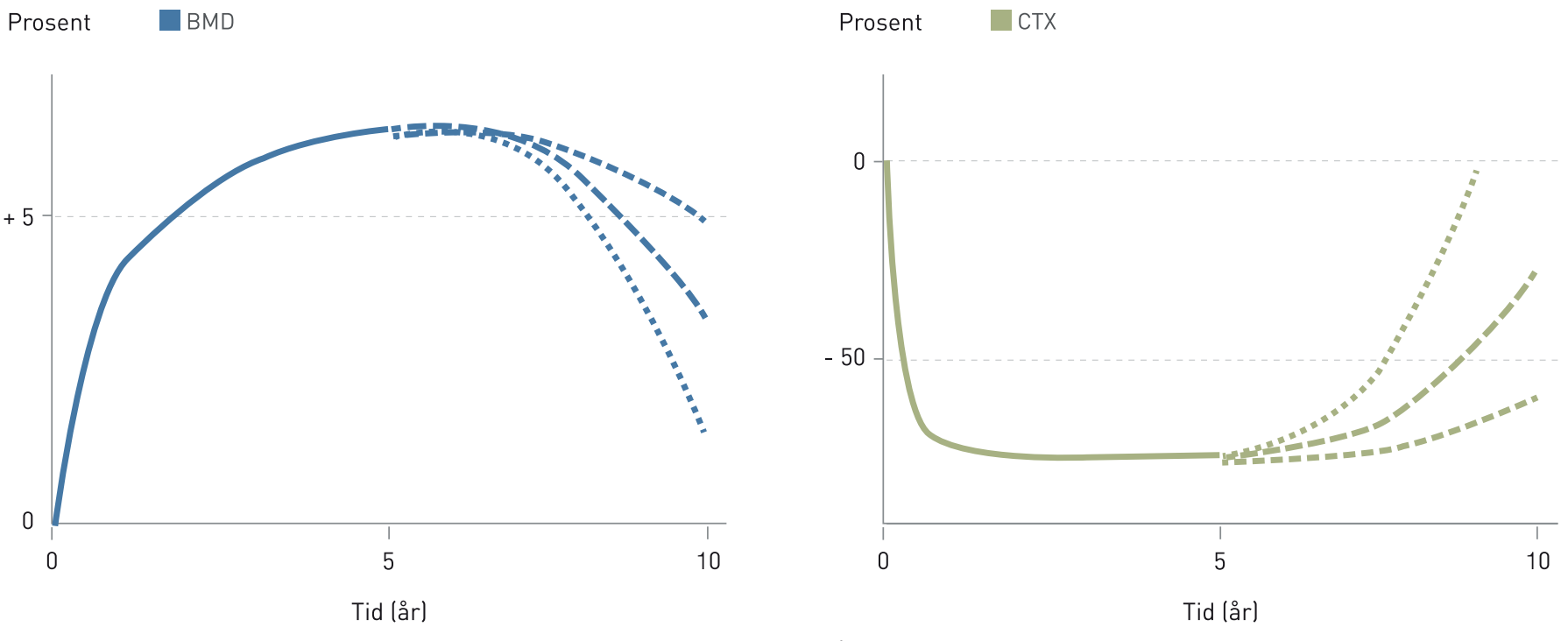

Figur 1 Kurvene beskriver mulige endringer av al beinmineraltettheten (BMD) og b) en resorpsjonsmarkør (CTX) som følge av seponering av bisfosfonat etter fem års kontinuerlig behandling. De tre kurvene beskriver det teoretiske gjennomsnittsforløpet etter seponering av et lavpotent (....), middels potent (-----) og høypotent (----) bisfosfonat. Potensen er en funksjon av to faktorer: binding til hydroksyapatitt og hemming av farnesylpyrofosfat syntetase (FPP), som er nøkkelenzymet i mevalonatstoffskiftesyklusen. Merk ulik skala på y-aksen i a og b 


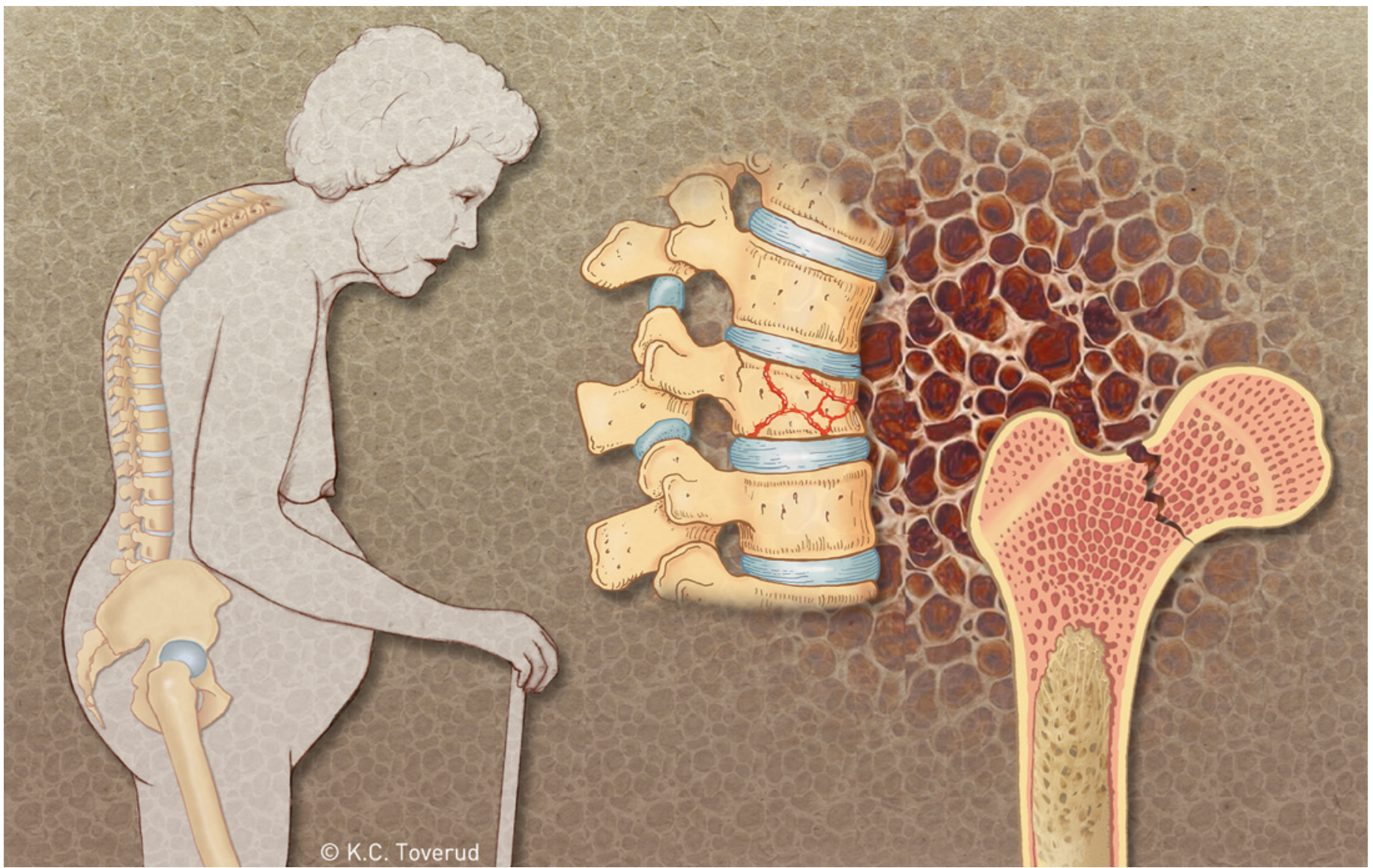

diskutert behovet for behandlingspauser etter langvarig bisfosfonatbehandling.

Slik vi ser det, er den viktigste grunnen til å overveie behandlingspauser imidlertid å utnytte bisfosfonaters spesielle farmakokinetikk. Bisfosfonater lagres i beinvevet og kan derfor påvirke beinremodellering lenge etter seponering. Ved å utnytte denne egenskapen i en behandlingspause, kan man bevare redusert beinremodellering, redusere tap av beinmasse og dermed gi beskyttelse mot frakturer uten å administrere ekstra medisin. Det er ressursbesparende for samfunnet og samtidig enklere og billigere for pasienten.

FLEX-studien viste at beinremodelleringen forble lav og beinmassen økte i opptil fem år etter opphør av alendronatbehandling (5). I en post hoc-analyse av denne studien undersøkte Schwartz og medarbeidere risikoen for brudd i forhold til oppnådd beinmineraltetthet $\mathrm{i}$ hoften etter fem års bisfosfonatbehandling (8). De viste at pasienter med T-skår $<-2,5$ hadde effekt av fortsatt behandling, mens pasienter med T-skår $>-2,0$ ikke viste ytterligere reduksjon $i$ antall brudd under fortsatt alendronatbehandling de neste fem år. Det skal anføres at analysen kun omfattet risikoen for ikkevertebrale brudd blant kvinner uten nye ryggbrudd.

Liknende data er nå publisert for zoledronat. Etter tre årlige infusjoner ble pasientene randomisert til enten ytterligere tre års infusjoner eller kalsium og vitamin D-tilskudd. Etter seks år var det mellom gruppene kun små forskjeller i beinmineraltetthet ved DXA-måling og beinmarkører (9). Til tross for dette viste denne studien at gruppen som fikk kortere behandling hadde en signifikant økning av ryggfrakturer sammenliknet med gruppen som fortsatte behandlingen, mens risikoen for ikke-vertebrale frakturer var den samme i begge grupper (9). Som i FLEX-studien viste en post hoc-analyse at T-skår $>-2,5$ var en rimelig grenseverdi for å starte behandlingspause, og denne gang fant man at det gjaldt både ryggbrudd og ikke-vertebrale brudd (10). Hvis pasientene hadde fătt nye brudd under behandlingen, skulle behandlingen fortsette uansett (10).

\section{Når kan man stoppe bisfosfonatbehandling?}

Under behandling med bisfosfonater er målet stadig å øke beinmineraltettheten og redusere biokjemiske beinmarkører i serum til verdier som ligger ved nedre grense av normalområdet. Vår anbefaling er basert på post hoc-analyser av sammenhengen mellom serumnivåer av beinmarkører og frakturrisiko i alendronat- og zoledronatstudiene, som begge viste at et lavere nivå av beinmarkører var assosiert med lavere frakturrisiko $(11,12)$. Beinmarkørene reflekterer beinremodellering, og i denne sammenheng har vi for monitorering av osteoblastfunksjon valgt prokollagen type 1 $\mathrm{N}$-terminal propeptid (PINP), osteokalsin og beinspesifikk alkalisk fosfatase og for monitorering av osteoklastfunksjon har vi valgt C-terminal telopeptid (CTX).

3-5 års behandling er et minimum, og den første forutsetningen for behandlingspause er at pasienten har hatt den forventede økningen i beinmineraltetthet og suppresjon av beinmarkører. Mange pasienter vil fortsatt ha lav beinmineraltetthet, og noen vil ha utviklet nye brudd til tross for slik behandling. Så hvilken pasient er velegnet for behandlingspause? Vi understreker ordet «pause», idet man ikke kan forvente varige positive effekter av bisfosfonatbehandling. Mange pasienter må etter en variabel periode settes tilbake på bisfosfonater eller starte med annen osteoporosebehandling.

En pragmatisk tilnærming vil derfor være at man behandler i 3-5 år og så beslutter om man skal fortsette behandlingen basert på T-skår i hoften etter den perioden. Er den $<-2,5$, fortsetter man opptil ti år eller inntil T-skår er $>-2,5$. Hvis derimot T-skåren har beveget seg opp over $-2,5$ etter 3-5 år, kan man ta en pause. Da må man fortsatt ha jevnlig kontroll av beinmineraltetthet og beinmarkører hvert år eller annethvert år. Hvis beinmarkører i denne pausen viser klar økning (opp mot midten av normalområdet) og/eller beinmineraltettheten reduseres signifikant (> 3-4\%) (fig 1), bør man overveie 
å starte behandling igjen, enten med bisfosfonat eller et annet medikament som denosumab, parathyreoideahormon (PTH) eller raloksifen. Hvis en pasient har fătt en ny fraktur under pågående behandling, er det tegn på så dårlig beinkvalitet at behandlingspause ikke kommer på tale. Her anbefales fortsatt aktiv behandling eller bytte til et annet medikament, som for eksempel denosumab eller parathyroideahormon. Tilsvarende overveielser bør også gjøres for pasienter som etter langtidsbehandling med et bisfosfonat fortsatt har svært lave beinmineraltetthetsverdier $(<-3,0)$.

Osteoporosebehandling med bisfosfonater er kostnadseffektivt for store pasientgrupper og kostnadsbesparende for mange kvinner $(13,14)$. Det finnes ingen analyser av kostnadseffektiviteten ved pauser i bisfosfonatbehandlingen, men det er rimelig å anta at en slik pause vil øke kostnadseffektiviteten. De største gevinstene tror vi vil være en enklere hverdag for pasienten som slipper å ta medisiner og redusert risiko for bivirkninger. For flere pasientgrupper, for eksempel de eldste og de med sekundære osteoporoseformer, mangler man kunnskap om muligheten for å ta pauser i behandlingen. I prinsippet vil de overveielser vi her har gjort for postmenopausal osteoporose også kunne gjelde for andre pasientgrupper.

\section{Konklusjon}

Osteoporosebehandling bør prinsipielt foregå livet ut, men i praksis er det meget få pasienter som forblir i livslang behandling på grunn av dårlig etterlevelse. Bisfosfonater akkumuleres i skjelettet og bygger derved opp et reservoar som kan mobiliseres, og når det er stort nok, kan det utnyttes under behandlingspauser. Seponering av bisfosfonatbehandling er derfor ikke indisert så mye på grunn av mulige sjeldne bivirkninger, men snarere for å utnytte residualeffekten på skjelettet etter seponering. Dette sparer utgifter for pasient og samfunn og kan kanskje forbedre etterlevelsen. Som vist ovenfor finnes det til nå lite forskning som kan hjelpe oss med å selektere egnede pasienter til en slik strategi, men flere analyser er på vei. Flere studier har vist at enhver seponering av bisfosfonat generelt øker risikoen for brudd hos pasienten. Ved å selektere pasienter med den beste behandlingsresponsen og de som ligger innenfor normalen for alder etter behandling, reduseres denne risikoen betydelig.

\section{Erik Fink Eriksen (f. 1953)}

er dr.med og spesialist $i$ indremedisin og endokrinologi og er seksjonsoverlege ved Endokrinologisk avdeling, Oslo universitetssykehus. Forfatter har fylt ut ICMJE-skjemaet og oppgir følgende interessekonflikter: Erik Fink Eriksen har mottatt konsulent- og styrehonorar samt støtte til reiser og møter fra Amgen, Novartis og Eli Lilly. Han har også mottatt honorarer for foredrag fra Eli Lilly og Novartis og støtte til utvikling av læremateriell fra Eli Lilly.

\section{Johan Halse (f. 1944)}

er dr.med, spesialist i indremedisin og endokrinologi og arbeider ved Osteoporoseklinikken, Spesialistsenteret Pilestredet Park.

Forfatter har fylt ut ICMJE-skjemaet og oppgir følgende interessekonflikter: Johan Halse har tatt konsulentoppdrag for Amgen, MSD og Novartis, drevet foredragsvirksomhet for MSD Norge, Novartis Norge, Nycomed, Eli Lilly, Amgen Norge, GSK, Pfizer, Roche og Novo Nordisk. Han har dessuten mottatt bidrag til kongressreiser fra MSD, Novartis, Roche, Amgen, Nycomed og Eli Lilly.

\section{Litteratur}

1. Cummings SR, Black DM, Thompson DE et al. Effect of alendronate on risk of fracture in women with low bone density but without vertebral fractures: results from the Fracture Intervention Trial. JAMA 1998; 280: 2077-82.

2. Harris ST, Watts NB, Genant HK et al. Effects of risedronate treatment on vertebral and nonvertebral fractures in women with postmenopausal osteoporosis: a randomized controlled trial. JAMA 1999; 282: $1344-52$

3. Black DM, Delmas PD, Eastell R et al. Once-yearly zoledronic acid for treatment of postmenopausal osteoporosis. N Engl J Med 2007; 356: 1809-22.
4. Odvina CV, Zerwekh JE, Rao DS et al. Severely suppressed bone turnover: a potential complication of alendronate therapy. J Clin Endocrinol Metab 2005; 90: 1294-301.

5. Black DM, Schwartz AV, Ensrud KE et al. Effects of continuing or stopping alendronate after 5 years of treatment: the Fracture Intervention Trial Long term Extension (FLEX): a randomized trial. JAMA 2006; 296: 2927-38.

6. Khosla S, Burr D, Cauley J et al. Bisphosphonateassociated osteonecrosis of the jaw: report of a task force of the American Society for Bone and Mineral Research. J Bone Miner Res 2007; 22: 1479-91.

7. Schilcher J, Michaëlsson K, Aspenberg P. Bisphosphonate use and atypical fractures of the femoral shaft. N Engl J Med 2011; 364: 1728-37.

8. Schwartz AV, Bauer DC, Cummings SR et al. Efficacy of continued alendronate for fractures in women with and without prevalent vertebral fracture: the FLEX trial. J Bone Miner Res 2010; 25: $976-82$.

9. Black DM, Cosman F. Eastell $R$ et al. The effect of 3 versus 6 years of zoledronic acid treatment in osteoporosis: a randomized extension to the HORIZON-Pivotal Fracture Trial (PFT). American Society for Bone and Mineral Research (ASBMR) Annual Meeting. October 16, 2010. www.asbmr.org/Meetings/AnnualMeeting/ AbstractDetail.aspx?aid=4781a020-dc3a-46beb49d-f706b5509c4e (12.6.2012).

10. Cosman F, Cauley J, Eastell R et al. Who is at highest risk for new vertebral fractures after 3 years of annual zoledronic acid and who should remain on treatment? American Society for Bone and Mineral Research (ASBMR) Annual Meeting. September, 2011. www.asbmr.org/Meetings/ AnnualMeeting/Abstract2011.aspx (12.6.2012).

11. Bauer DC, Black DM, Garnero P et al. Change in bone turnover and hip, non-spine, and vertebral fracture in alendronate-treated women: the fracture intervention trial. J Bone Miner Res 2004: 19: $1250-8$

12. Delmas PD, Munoz F, Black DM et al. Effects of yearly zoledronic acid $5 \mathrm{mg}$ on bone turnover markers and relation of PINP with fracture reduction in postmenopausal women with osteoporosis. J Bone Miner Res 2009; 24: 1544-51.

13. Akehurst R, Brereton N, Ariely R et al. The cost effectiveness of zoledronic acid $5 \mathrm{mg}$ for the management of postmenopausal osteoporosis in women with prior fractures: evidence from Finland, Norway and the Netherlands. J Media Econ 2011; 14: 53-64.

14. Ström 0, Borgström F. Sen SS et al. Cost-effectiveness of alendronate in the treatment of postmenopausal women in 9 European countries-an economic evaluation based on the fracture intervention trial. Osteoporos Int 2007; 18: 1047-61.

Mottatt 11.7. 2011, første revisjon innsendt 8.12 2011, godkjent 25.5. 2012. Medisinsk redaktør Mette Sagsveen. 